\title{
Antibacterial Aromatic Polyketides Incorporating the Unusual Amino Acid Enduracididine
}

Paolo Monciardini, ${ }^{*},+, \|_{\odot}$ Alice Bernasconi, ${ }^{\dagger, \|}$ Marianna Iorio, ${ }^{\dagger}$ Cristina Brunati, ${ }^{\ddagger}$ Margherita Sosio, ${ }^{\dagger, \dagger}$ Laura Campochiaro, ${ }^{\dagger}$ Paolo Landini, ${ }^{\S}$ Sonia I. Maffioli, ${ }^{\dagger, \dagger}$ and Stefano Donadio ${ }^{\dagger, \dagger}$

${ }^{\dagger}$ NAICONS Srl, Viale Ortles 22/4, 20139 Milano, Italy

${ }^{\ddagger}$ KtedoGen Srl, Viale Ortles 22/4, 20139 Milano, Italy

${ }^{\S}$ Bioscience Department, Università degli Studi di Milano, Via Celoria 2, 20122 Milano, Italy

Supporting Information

ABSTRACT: The increasing incidence of infections caused by drug-resistant pathogens requires new efforts for the discovery of novel antibiotics. By screening microbial extracts in an assay aimed at identifying compounds interfering with cell wall biosynthesis, based on differential activity against a Staphylococcus aureus strain and its isogenic L-form, the potent enduracyclinones $(\mathbf{1}, 2)$, containing the uncommon amino acid enduracididine linked to a six-ring aromatic skeleton, were discovered from different Nonomuraea strains. The structures of 1 and 2 were established through a combination of derivatizations, oxidative cleavages, and NMR analyses of natural and ${ }^{13} \mathrm{C}-{ }^{15} \mathrm{~N}$-labeled compounds. Analysis of the biosynthetic cluster provides the combination of genes for the

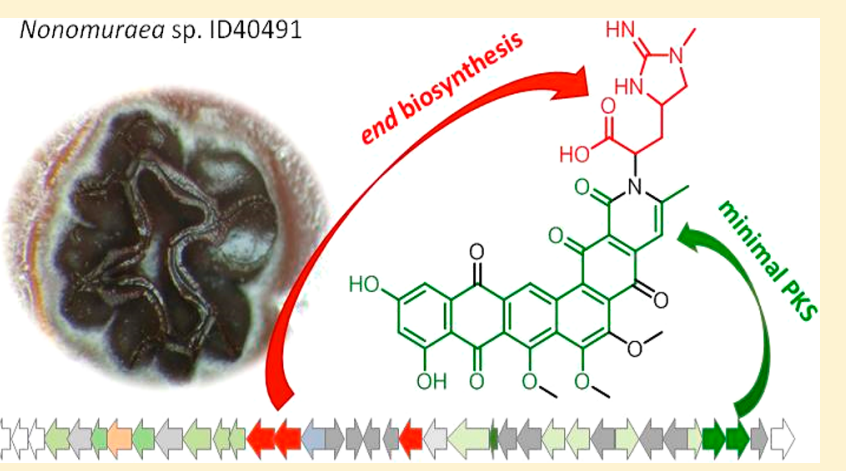
synthesis of enduracididine and type II polyketide synthases. Enduracyclinones are active against Gram-positive pathogens (especially Staphylococcus spp.), including multi-drug-resistant strains, with minimal inhibitory concentrations in the range of 0.0005 to $4 \mu \mathrm{g} \mathrm{mL}^{-1}$ and with limited toxicity toward eukaryotic cells. The combined results from assays and macromolecular syntheses suggest a possible dual mechanism of action in which both peptidoglycan and DNA syntheses are inhibited by these molecules.

$\mathrm{O}$ ur ability in controlling infections, which has been taken for granted for decades after the introduction in clinical practice of antibiotics, is currently at risk due to the continuous rise of infections sustained by antibiotic-resistant microorganisms. Multi-drug-resistant pathogens are now routinely isolated, severely impairing our ability to manage bacterial infections. ${ }^{1,2}$ To address this threat to human (and animal) health requires increased efforts toward discovery and development of novel anti-infective substances, not affected by prevailing resistance mechanisms. ${ }^{1,2}$ Ideally, novel antimicrobials should belong to new chemical classes to minimize cross-resistance with marketed antibiotics. ${ }^{3}$ Natural products represent a major source of approved antibacterials: ${ }^{4,5}$ the majority of antibiotics in clinical use are microbial metabolites or their derivatives, typically from actinomycetes. ${ }^{2,4}$ Despite extensive screening during the "golden era" of antibiotic discovery, molecules with novel structures and modes of action can still be found among microbial metabolites. Recent examples include teixobactin ${ }^{6}$ and pseudouridimycin, ${ }^{7}$ which, although acting on well-established bacterial targets (cell wall and RNA biosynthesis, respectively), do so with mechanisms differing from those of other molecules targeting the same pathways and thus are active against resistant pathogens.
In our search for novel classes of antibacterial molecules, we have previously described an approach based on mining our proprietary database, which contains results of several antibacterial high-throughput-screening (HTS) assays performed on more than 100000 microbial extracts. ${ }^{8}$ While HTS applies rigid filters for identifying a workable number of candidates for further analyses, a posteriori evaluation of the HTS data permits selection of candidates that were not previously pursued. By re-evaluating data from an HTS phenotypic screen aimed at identifying molecules inhibiting bacterial cell wall biosynthesis, ${ }^{9}$ we have reported different lanthipeptides, ${ }^{10,11}$ including compounds with unusual structural features and unexpected bioactivities. ${ }^{10-12}$

Here we further expand on this data mining approach and report on the isolation of aromatic polyketides containing the uncommon amino acid enduracididine installed on a fused sixring skeleton. These molecules, dubbed enduracyclinones, are highly active against Gram-positive pathogens, including antibiotic-resistant strains.

Received: May 4, 2018

Published: January 7, 2019 


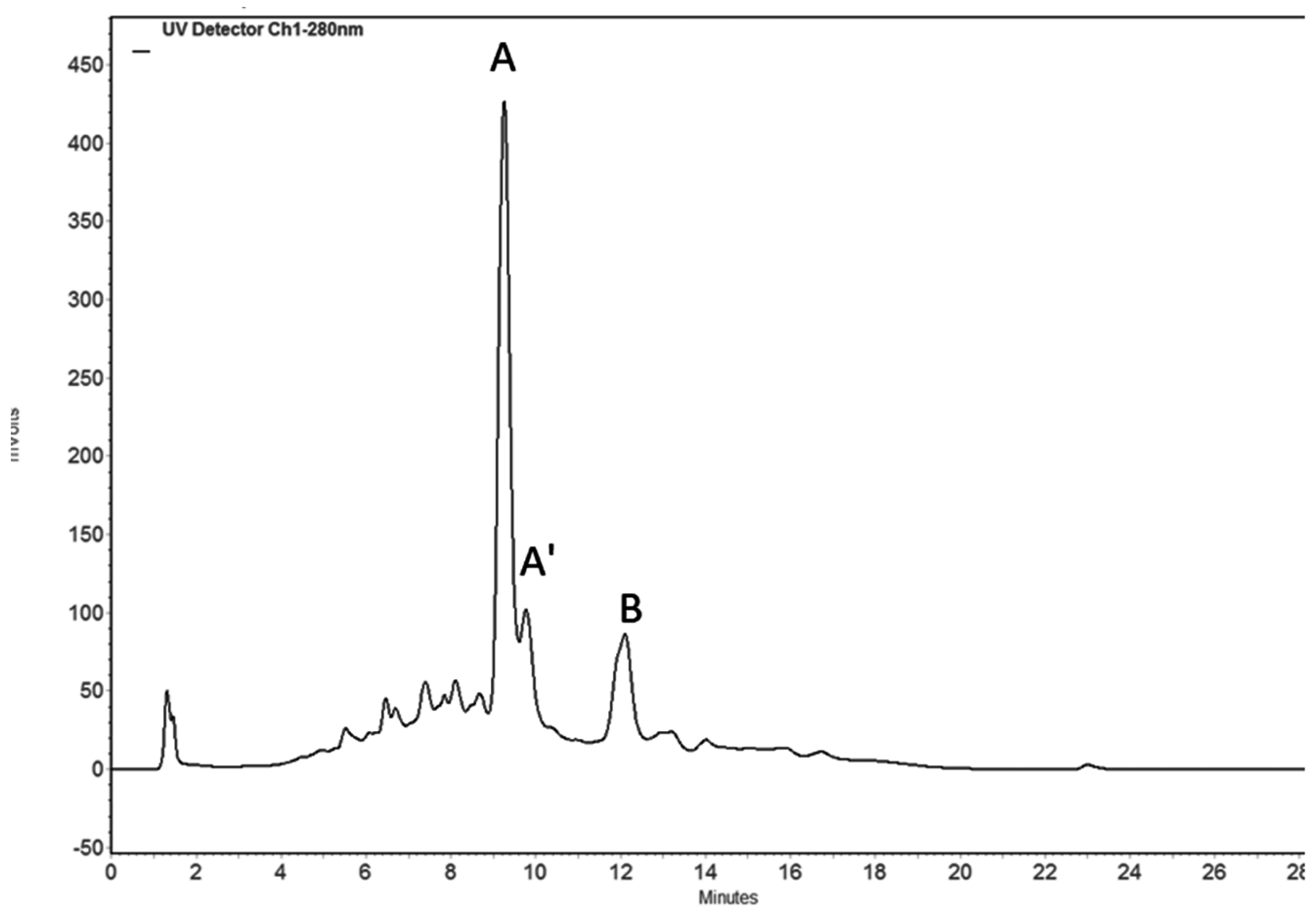

Figure 1. HPLC trace of an ethanol extract from strain ID40491 (see text for details).

\section{RESULTS AND DISCUSSION}

Data Mining. The HTS database contains data on a phenotypic assay aimed at identifying likely inhibitors of bacterial cell wall biosynthesis. About 120000 microbial fermentation extracts were analyzed by an assay based on differential activity against a Staphylococcus aureus strain and its isogenic L-form, i.e., a variant empirically adapted to grow in the absence of a cell wall in an osmotic-protective medium. ${ }^{9}$ Extracts inhibiting growth of $S$. aureus at a concentration at least 8 times lower than that required for growth inhibition of the L-form were assumed to interfere with cell wall biosynthesis. Positive samples were further assayed for maintenance of activity after incubating the extracts with beta-lactamases or with D-Ala-D-Ala (these tests were meant to discard $\beta$ lactamase-sensitive compounds and D-Ala-D-Ala binders, respectively) before further characterization. By searching the HTS database, however, we identified 17 extracts that, albeit fulfilling the selection criteria (lack of or reduced activity against L-forms), had not been further analyzed during the original screening. The corresponding strains were therefore processed, and the extracts obtained from 12 cultures confirmed activity against $S$. aureus. Ten of these extracts retained activity against one multi-drug-resistant (MDR) $S$. aureus strain and were further processed (Supplementary Table S1). One extract was found to contain the lantibiotic NAI$802,{ }^{10}$ a variant of actagardine likely to target cell wall biosynthesis, and another extract was found to contain the thiopeptide nosiheptide, a molecule whose primary target is translation but which, for unknown reasons, is known to be less active against L-forms. ${ }^{13}$ The other eight strains produced the same compound, as described below.

Discovery of Enduracyclinones from Nonomuraea spp. Extracts from the eight strains contained the same active fractions correlating to peaks with retention times of 9.5 (major peak), 10, and 12 min (peaks $\mathrm{A}, \mathrm{A}^{\prime}$, and $\mathrm{B}$, respectively, as shown in Figure 1). The peaks showed $m / z[\mathrm{M}+\mathrm{H}]^{+}$of
711, 697, and 713, respectively, and similar UV-vis spectra (absorption maxima were at 244, 283, 334, and $445 \mathrm{~nm}$ for peak A). The molecules appeared to be very stable in MS fragmentation conditions, with the ready loss of only a $44 \mathrm{amu}$ fragment.

The corresponding eight actinomycete strains were analyzed by comparing their nearly complete $16 \mathrm{~S}$ rRNA gene sequences and assigned to three distinct lineages within the genus Nonomuraea (Supplementary Table S1). One of the lineages is represented by six strains isolated from four soil samples collected in different locations in Italy or from plant specimens from Scotland and Italy. These strains showed 99.7-100\% identity in the 16S rRNA gene sequences among themselves and to Nonomuraea endophytica. The two additional lineages are represented by a single strain each, originating from Kenyan and Honduras soils and showing relatively low $16 \mathrm{~S}$ identity with described species (98.4\% with Nonomuraea candida or $98.9 \%$ with Nonomuraea salmonea). Comparable levels of the peaks correlated to biological activity were observed for the six European strains, and strain ID40491 was chosen for further analyses. Under the best conditions, strain ID40491 produced about $500 \mathrm{mg} \mathrm{L}^{-1}$ peak A. The remaining European strains produced at least $100 \mathrm{mg} \mathrm{L}^{-1}$ peak A.

Purification and Structure Elucidation. The active peaks were associated with both the mycelium and the cleared broth. Therefore, both mycelium and cleared broth were processed, and the active compounds were retrieved by exploiting their low aqueous solubility at $\mathrm{pH} 5$ and their increased solubility at $\mathrm{pH}$ 9. Further purification afforded a sample containing HPLC peaks $A$ and $A^{\prime}$ in a 9:1 ratio and another containing $A, B$, and $A^{\prime}$ in a 5:3:2 ratio. From the first sample a small amount of a highly pure A peak sample was generated (see Experimental Section for purification procedures). To help structure elucidation, the ${ }^{13} \mathrm{C}-{ }^{15} \mathrm{~N}$-labeled compounds were also prepared by growing strain ID40491 in a uniformly labeled medium (see Experimental Section) that 

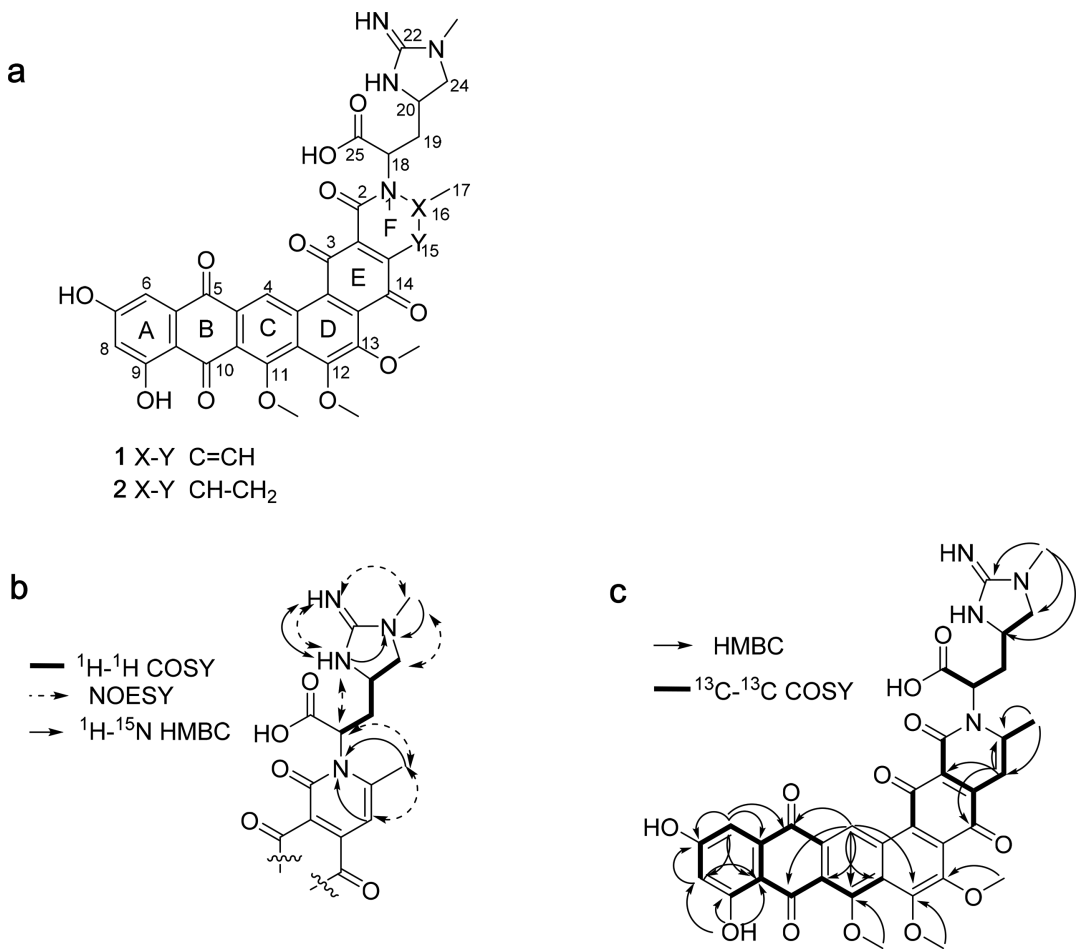

Figure 2. Structures of compounds and NMR correlations. (a) Structures of 1 and 2. (b) Main ${ }^{1} \mathrm{H}-{ }^{1} \mathrm{H}$ COSY, NOESY, and ${ }^{1} \mathrm{H}-{ }^{15} \mathrm{~N}$ HMBC correlations. (c) Observed HMBC and ${ }^{13} \mathrm{C}-{ }^{13} \mathrm{C}$ COSY correlations of $\mathbf{1}$.

afforded a purified sample of peaks $\mathrm{A}$ and $\mathrm{A}^{\prime}$ (in a 9:1 ratio) with a $95 \%{ }^{13} \mathrm{C}$ - and ${ }^{15} \mathrm{~N}$-enrichment (Supplementary Figure S1). Unless otherwise stated, all chemical and bioactivity analyses were performed on samples containing peaks $\mathrm{A}$ and $\mathrm{A}^{\prime}$ in a 9:1 ratio.

The main congener 1 (peak A) has a molecular formula of $\mathrm{C}_{36} \mathrm{H}_{30} \mathrm{~N}_{4} \mathrm{O}_{12}$ with 24 double-bond equivalents, as deduced by high resolution mass spectrometry (HRMS). In the presence of trimethylsilyldiazomethane, a 14 amu heavier product was formed, consistent with a methyl ester of 1 , while $N, N$ dimethylpropylamine in the presence of condensing agents converted 1 into a $m / z 795[\mathrm{M}+\mathrm{H}]^{+}$compound, consistent with the formation of the corresponding amide. The MS/MS data (loss of $44 \mathrm{amu}$, see above) and the results from these reactions suggested the presence of a free carboxylic acid. The structure of 1 (Figure 2) was established by a combination of one- and two-dimensional NMR analyses, performed on the natural and the ${ }^{13} \mathrm{C}-{ }^{15} \mathrm{~N}$-labeled compound, and confirmed by selective oxidative cleavage, as explained below.

$1 \mathrm{D}$ and 2D NMR analyses established the presence of a polycyclic aromatic system linked to a nitrogen-rich aliphatic acid. The ${ }^{1} \mathrm{H}$ NMR data (Table 1, Figure 2) of $\mathbf{1}$ displayed four aromatic protons at $\delta_{\mathrm{H}} 9.58,6.80,7.14$, and $6.64 \mathrm{ppm}$, the latter two showing a meta-coupling constant $(J=2.1 \mathrm{~Hz})$; three methoxy $\left(\delta_{\mathrm{H}} 3.98\right.$, overlapped $)$, one $N$-methyl $\left(\delta_{\mathrm{H}} 2.89\right)$ and one C-methyl $\left(\delta_{\mathrm{H}} 2.59\right)$; two nitrogen-bound protons at $\delta_{\mathrm{H}} 8.17$ and $8.03 \mathrm{ppm}$; and two phenolic signals at $\delta_{\mathrm{H}} 11.30$ and $13.30 \mathrm{ppm}$. In addition, the major spin system corresponded to a four-carbon chain formed by an amino acid-alpha proton at $\delta_{\mathrm{H}} 5.05 \mathrm{ppm}(\mathrm{H}-18)$ directly connected to a $\mathrm{CH}_{2}$ at 2.02-2.73 ppm (H-19a and b), followed by another $\mathrm{CH}$ at $4.09 \mathrm{ppm}(\mathrm{H}-20)$ and a further diasterotopic methylene at 3.30-3.84 ppm (H-24a and b). The analysis of proton and carbon chemical shifts (Table 1) together with correlation spectroscopy (COSY), total correlation spectroscopy
(TOCSY), and nuclear Overhauser enhancement spectroscopy (NOESY) correlations suggested that C-20 and C-24 are trapped in a rigid structure. Furthermore, a guanidine unit was identified through the heteronuclear multiple bond correlation (HMBC) of the $N$-methyl group to an $\mathrm{sp}^{2}$ carbon at $\delta_{\mathrm{C}} 158.2$ ppm (C-22) and the NOESY signals of the proton at $8.02 \mathrm{ppm}$ with the proton at $8.17 \mathrm{ppm}$ and the $N$-methyl group. Moreover, the NOESY correlation of the $N$-methyl group with one of the methylene protons at $\mathrm{C}-24\left(\mathrm{H}-24 \mathrm{~b}\right.$, at $\left.\delta_{\mathrm{H}} 3.84 \mathrm{ppm}\right)$ and of the alpha proton at $5.05 \mathrm{ppm}$ with the proton at 8.17 ppm and with the C-methyl at $2.59 \mathrm{ppm}$ established that the rigid structure is a five-membered ring arising from an $N$ methyl enduracididine linked through the $\alpha$-amino group to the aromatic system.

Heteronuclear single quantum coherence (HSQC), HMBC, and monodimensional ${ }^{13} \mathrm{C}$ experiments highlighted the presence of four quinonic carbonyls at $\delta_{\mathrm{C}} 181.4,181.9$, 182.4 , and $185.6 \mathrm{ppm}$, a carboxyl carbon at $\delta_{\mathrm{C}} 169.8$, and two other carbonyls at $\delta_{\mathrm{C}} 158.0$ and 158.2. A key signal was the aromatic $\mathrm{CH}-4$, with a peculiar chemical shift at $\delta_{\mathrm{H}} 9.58 \mathrm{ppm}$, correlating to a carbon at $\delta_{\mathrm{C}} 125 \mathrm{ppm}$. It is known that aromatic hydrogens peri to quinones in natural anthraquinones are deshielded, with values ranging from 7.5 to 8.3 ppm. ${ }^{14,15}$ In our case, $\mathrm{H}-4$ appeared even more deshielded, suggesting the presence of a second quinone (E ring), linked angularly to the tetracyclinone ( $\mathrm{A}-\mathrm{D}$ rings). Moreover, this proton gave $\mathrm{HMBC}$ correlations with quinones $\mathrm{C}-5$ and $\mathrm{C}-10$, aromatic carbons $\mathrm{C}-10 \mathrm{a}$ and $11 \mathrm{a}$, and the methoxy-substituted aromatic carbons $\mathrm{C}-11$ and $\mathrm{C}-12$, thus establishing the core $\mathrm{A}-\mathrm{E}$ ring structure.

The relative position of the two quinone moieties was confirmed by treatment with $20 \% \quad \mathrm{H}_{2} \mathrm{O}_{2}$ at $60{ }^{\circ} \mathrm{C}$ (see Experimental Section for details). ${ }^{16,17}$ Under these conditions both quinones were oxidatively cleaved, leading to the formation of a major species at $m / z 637[\mathrm{M}+\mathrm{H}]^{+}$, 
Table 1. NMR Spectroscopic Data (300 MHz, DMSO- $d_{6}$ ) for Enduracyclinone A in DMSO- $d_{6}$

\begin{tabular}{|c|c|c|c|}
\hline position & $\delta_{\mathrm{C}}$, type & $\delta_{\mathrm{H}}(J$ in $\mathrm{Hz})$ & $\delta_{\mathrm{N}}$, type \\
\hline 1 & & & 197.3, N \\
\hline 2 & 158.0, C & & \\
\hline $2 a$ & 118.7, C & & \\
\hline 3 & 182.3, C & & \\
\hline $3 a$ & $129,8, \mathrm{C}$ & & \\
\hline $3 b$ & 131.2, C & & \\
\hline 4 & $125.5, \mathrm{CH}$ & $9.58, \mathrm{~s}$ & \\
\hline 4 a & 130.6, C & & \\
\hline 5 & 181.4, C & & \\
\hline $5 a$ & $134.8, \mathrm{C}$ & & \\
\hline 6 & 107.3, CH & $7.14, \mathrm{~d}(2.1)$ & \\
\hline 7 & $164.8, \mathrm{C}$ & & \\
\hline $\mathrm{OH}(7)$ & & 11.30 , br s & \\
\hline 8 & $108.4, \mathrm{C}$ & $6.64, \mathrm{~d}(2.1)$ & \\
\hline 9 & 165.1, C & & \\
\hline $\mathrm{OH}(9)$ & & $13.30, \mathrm{~s}$ & \\
\hline 9 a & 111.6, C & & \\
\hline 10 & 185.6, C & & \\
\hline $10 \mathrm{a}$ & 122.1, C & & \\
\hline 11 & 159.2, C & & \\
\hline $\mathrm{OMe}(11)$ & $63.2, \mathrm{CH}_{3}$ & $3.98 \mathrm{~s}$ & \\
\hline $11 \mathrm{a}$ & 130.5, C & & \\
\hline 12 & 155.6, C & & \\
\hline $\mathrm{OMe}(12)$ & 62.6, $\mathrm{CH}_{3}$ & $3.98 \mathrm{~s}$ & \\
\hline 13 & $150.8, \mathrm{C}$ & & \\
\hline $\mathrm{OMe}(13)$ & $61.9, \mathrm{CH}_{3}$ & $3.97 \mathrm{~s}$ & \\
\hline $13 a$ & 130.4, C & & \\
\hline 14 & 181.9, C & & \\
\hline $14 \mathrm{a}$ & 143.6, C & & \\
\hline 15 & $101.8, \mathrm{CH}$ & $6.80 \mathrm{~s}$ & \\
\hline 16 & $155.5, \mathrm{C}$ & & \\
\hline 17 & 22.3, $\mathrm{CH}_{3}$ & $2.59, \mathrm{~s}$ & \\
\hline 18 & $56.6, \mathrm{CH}$ & $5.05, \mathrm{~m}$ & \\
\hline 19 & $35.1, \mathrm{CH}_{2}$ & $2.02, \mathrm{~m}-2.73, \mathrm{~m}$ & \\
\hline 20 & $50.9, \mathrm{CH}$ & $4.09, \mathrm{~m}$ & \\
\hline $21 \mathrm{NH}$ & & 8.17 , br s & $90.4, \mathrm{NH}$ \\
\hline 22 & 158.2, C & & \\
\hline $22 \mathrm{NH}$ & & 8.02 br s & 71.3, NH \\
\hline 23 & & & $77.0, \mathrm{~N}$ \\
\hline $\mathrm{Me}(23)$ & $31.4, \mathrm{CH}_{3}$ & $2.89, \mathrm{~m}$ & \\
\hline 24 & $55.2, \mathrm{CH}_{2}$ & $3.38, \mathrm{~m}-3.84, \mathrm{~m}$ & \\
\hline 25 & $169.8, \mathrm{C}$ & & \\
\hline
\end{tabular}

corresponding to the dicarboxylic product ox-1 following rupture of ring $B$ (Figure 3), and of species at $m / z 469[M+$ $\mathrm{H}]^{+}$(product ox-2) and $m / z 279[\mathrm{M}+\mathrm{H}]^{+}$(product ox-3), after breaking ring $\mathrm{E}$.

HMBCs of the two aromatic protons with meta-coupling constant $(J=2.1 \mathrm{~Hz})$ enabled placing the substituents on ring A, with positions 7 and 9 bearing two phenols with different NMR behavior: while OH-7 gives a broad singlet with no significant $2 \mathrm{D}$ correlations, $\mathrm{OH}-9$ presents a sharp signal at $\delta_{\mathrm{H}}$ $13.30 \mathrm{ppm}$ with HMBC correlations to C-8, C-9, and C-9a, suggesting that the phenol partakes in an intramolecular hydrogen bond with the quinone oxygen in peri position. The last ring, F, was established as a benzofused methyl-pyrimidone ring thanks to the $\mathrm{HMBC}$ correlations of proton $\mathrm{H}-15$ at $\delta_{\mathrm{H}}$ $6.80 \mathrm{ppm}$ with quinone $\mathrm{C}-14$, carbons $\mathrm{C}-2 \mathrm{a}$ and $\mathrm{C}-16$, and methyl 17.

${ }^{1} \mathrm{H}-{ }^{15} \mathrm{~N}-\mathrm{HMBC}$ and ${ }^{13} \mathrm{C}-{ }^{13} \mathrm{C}$ COSY analyses of ${ }^{13} \mathrm{C}-{ }^{15} \mathrm{~N}-$ labeled 1 allowed the assignment of all nitrogen chemical shifts and the identification of the cyclic amide, with $\mathrm{N}-1$ correlating to $\mathrm{CH}_{3}-17$ and $\mathrm{CH}-15$ (Table 1). Moreover, the majority of the carbon backbone connectivity of $\mathbf{1}$ was clearly established (Figure 2C).

As shown above (Figure 1), strain ID40491 produced also two minor congeners. Peak $A^{\prime}$ showed a difference of $14 \mathrm{amu}$ in comparison to 1 , suggesting the lack of a methyl group (found $m / z 697.1786[\mathrm{M}+\mathrm{H}]^{+}$for $\mathrm{C}_{35} \mathrm{H}_{28} \mathrm{~N}_{4} \mathrm{O}_{12}$, calcd 697.1776). During oxidative cleavage, we also observed the formation of a minor $m / z 455[\mathrm{M}+\mathrm{H}]^{+}$species along with product ox-2 (Figure 3), consistent with the lack of one of the three methoxy groups in rings $\mathrm{C}$ or $\mathrm{D}$. However, the amount of des-methyl-1 was insufficient for further analyses, so the exact position of the free $\mathrm{OH}$ in this minor congener remains to be established.

HRMS indicated that peak $B$ was associated with a $\mathrm{C}_{36} \mathrm{H}_{32} \mathrm{~N}_{4} \mathrm{O}_{12}$ species (compound 2 in Figure 2) with 23 unsaturations (found $\mathrm{m} / z$ 713.2104 $[\mathrm{M}+\mathrm{H}]^{+}, 713.2095$ calcd). The observation that, in the ${ }^{1} \mathrm{H}$ NMR spectrum of 1:2:desmethyl-1 5:3:2, Me-17 integrated less than expected and that $\mathbf{2}$ easily converted into $\mathbf{1}$ under oxidative conditions (see Experimental Section) suggested that $\mathbf{2}$ differs from $\mathbf{1}$ for the lack of the unsaturation in the pyrimidone ring $\mathrm{F}$ (Figure 2).

Structural Features of Enduracyclinones. Overall, the metabolites produced by strain ID40491 consist of a highly oxygenated angular hexacyclic framework linked to an $\mathrm{N}$ methylated enduracididine moiety. We therefore named the compounds enduracyclinones A (1) and B (2).

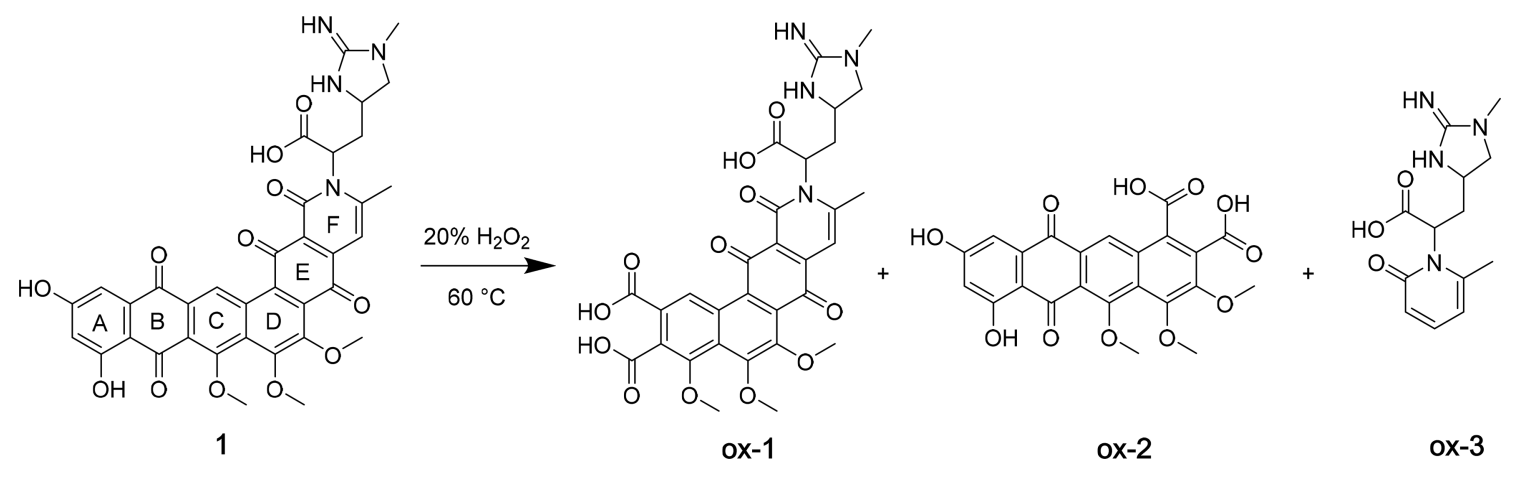

Figure 3. Oxidative cleavage of 1 . 


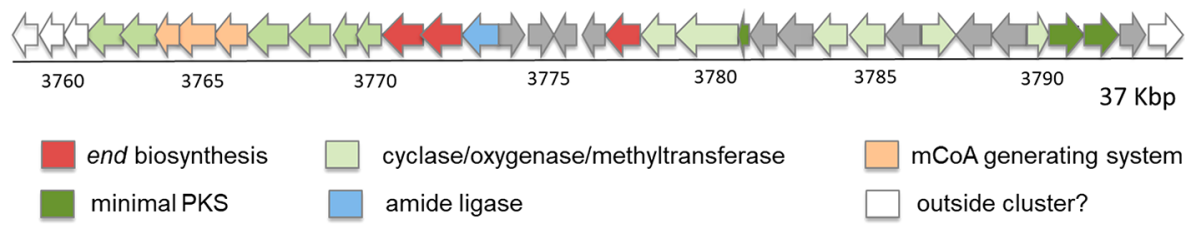

Figure 4. Organization of the enduracyclinone biosynthetic genes. The deduced functions are color-coded as indicated and summarized in Table 2. end, enduracididine; mCoA, malonyl-CoA.

Table 2. Coding DNA Sequences (CDSs) from the edc Cluster of Nonomuraea sp. ID40491 and Proposed Roles in the Pathway

\begin{tabular}{|c|c|c|c|c|}
\hline$e d c \mathrm{CDS}$ & $\begin{array}{l}\text { size } \\
\text { (aa) }\end{array}$ & homologue (strain, accession no. $)^{a}$ & $\begin{array}{l}\text { identity } \\
(\%)\end{array}$ & putative role \\
\hline Chr_03759 & 115 & 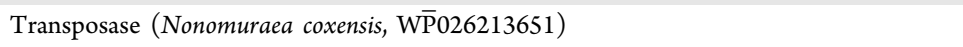 & 85 & outside cluster \\
\hline Chr_03760 & 612 & hypothetical protein (Streptomyces sp., CNS335) & 68 & unknown, outside cluster? \\
\hline Chr_03761 & 219 & DNA repair protein (Nonomuraea sp. NBRC 110462, W $\bar{P} 055503593.1$ ) & 77 & unknown, outside cluster? \\
\hline Chr_03762 & 350 & O-methyltransferase (Micromonospora echinospora, ADB23385) & 45 & cyclase-methyltransferase \\
\hline Chr_03763 & 219 & $\begin{array}{l}\text { putative leucyldemethylblasticidin S guanidine methyltransferase (Streptomyces } \\
\text { griseochromogenes, AAP03126.1) }\end{array}$ & 51 & methyltransferase \\
\hline Chr_03764 & 448 & PdmP1, biotin carboxylase (Actinomadura hibisca, ABM21735.1) & 61 & subunit of acetyl carboxylase \\
\hline Chr_03765 & 156 & $\begin{array}{l}\text { biotin carboxyl carrier protein of acetyl-CoA carboxylase (Streptomyces lydicus, } \\
\text { AJT61720.1) }\end{array}$ & 47 & subunit of acetyl carboxylase \\
\hline Chr_03766 & 542 & acetyl carboxylase (Streptomyces sp. R1128, AAG30193.1) & 60 & subunit of acetyl carboxylase \\
\hline Chr_03767 & 191 & GrhU, monooxygenase (Streptomyces sp. JP95, AAM33683.1) & 53 & monooxygenase \\
\hline Chr_03768 & 154 & putative monooxygenase (Streptomyces flavogriseus, ADE22312.1) & 39 & monooxygenase \\
\hline Chr_03769 & 150 & RubF, putative polyketide cyclase/reductase (Streptomyces collinus, AAG03070.2) & 67 & cyclase/reductase \\
\hline Chr_03770 & 107 & putative cyclase (Streptomyces collinus, AAG03065.2) & 71 & cyclase \\
\hline Chr_03771 & 372 & PLP-dependent aminotransferase MppQ (Streptomyces hygroscopicus, AAU34210) & 54 & enduracididine biosynthesis \\
\hline Chr_03772 & 374 & enduracididine biosynthesis enzyme MppP (Streptomyces hygroscopicus, AAU34209) & 63 & enduracididine biosynthesis \\
\hline Chr_03773 & 613 & PdmN, asparagine synthetase (Actinomadura hibisca, ABK58686.1) & 50 & $\begin{array}{l}\text { enduracididine-polyketide amide } \\
\text { synthase }\end{array}$ \\
\hline Chr_03774 & 249 & ABC transporter (Micromonospora sp., ALA09377.1) & 58 & export \\
\hline Chr_03775 & 649 & Sio5, ABC transporter (Streptomyces sioyaensis, ACN80636.1) & 30 & transporter \\
\hline Chr_03776 & 217 & Azi47, DNA-binding response regulator (Streptomyces sahachiroi, ABY83185.1) & 63 & DNA-binding response regulator \\
\hline Chr_03777 & 445 & regulatory protein D (Actinoplanes friuliensis, CAM56777.1) & 44 & regulator \\
\hline Chr_03778 & 270 & conserved hypothetical protein MppR (Streptomyces hygroscopicus, AAU34211.1) & 65 & enduracididine biosynthesis \\
\hline Chr_03779 & 317 & EpaU, cytochrome oxidase subunit II (Kitasatospora sp. HKI 714, AHW81480.1) & 39 & oxidase \\
\hline Chr_03780 & 419 & EpaT, cytochrome ubiquinol oxidase (Kitasatospora sp. HKI 714, AHW81479.1) & 56 & oxidase \\
\hline Chr_03781 & 85 & ACP (Streptomyces griseus, CAE17520.1) & 62 & $\mathrm{ACP}$ \\
\hline Chr_03782 & 512 & putative efflux protein (Streptomyces kanamyceticus, CAF60521.1) & 38 & transporter \\
\hline Chr_03783 & 32 & putative protease (Streptomyces olivoviridis, BAN83926.1) & 47 & unknown \\
\hline Chr_03784 & 494 & FAD-dependent monoxygenase (Micromonospora echinospora,ADB23401.1) & 48 & monoxygenase. hydroxylase \\
\hline Chr_03785 & 338 & putative O-methyltransferase (Streptomyces tendae Tu 4042, CAM34375.1) & 49 & O-methyltransferase \\
\hline Chr_03786 & 498 & putative peptide transporter (Streptomyces griseus ATCC 43944, AAQ08913.1) & 50 & transporter \\
\hline Chr_03787 & 393 & cytochrome P450 (Streptomyces sp. TA-0256, BAJ52675.1) & 53 & monoxygenase \\
\hline Chr_03788 & 221 & LuxR transcriptional regulator (uncultured bacterium, AHX24716.1) & 65 & regulator \\
\hline Chr_03789 & 373 & two component system histidine kinase (uncultured bacterium, AHX24717.1) & 40 & regulator \\
\hline Chr_03790 & 137 & cyclase (uncultured bacterium, AHX24700.1) & 69 & polyketide cyclase \\
\hline Chr_03791 & 420 & polyketide beta-ketoacyl synthase alpha (Streptomyces flavogriseus, ADE22315.1) & 77 & $\mathrm{KS} \alpha$ \\
\hline Chr_03792 & 400 & $\begin{array}{l}\text { Hex23, polyketide beta-ketoacyl synthase beta (Streptosporangium sp. CGMCC } 4.7309 \text {, } \\
\text { AMK51280.1) }\end{array}$ & 66 & $\mathrm{KS} \beta$ \\
\hline Chr_03793 & 259 & DacT1, DNA-binding response regulator (Dactylosporangium sp. SC14051, AFU65883.1) & 49 & transcriptional regulator \\
\hline Chr_03794 & 514 & $\begin{array}{l}\text { twin-arginine translocation pathway signal sequence (Kibdelosporangium aridum, } \\
\text { SMD27155) }\end{array}$ & 64 & outside cluster? \\
\hline
\end{tabular}

${ }^{a}$ Best match observed by BLAST analysis of clusters listed in the MIBIG database of validated biosynthetic gene clusters ${ }^{37}$ or from the nonredundant GenBank database. Abbreviations: ACC, acetylCoA carboxylase; ACP, acyl carrier protein; BCCP, biotin carboxylate carrier protein; $\mathrm{KS} \alpha$, type II polyketide synthase $\beta$-ketoacyl synthase, alpha subunit; $\mathrm{KS} \beta$, type II polyketide synthase $\beta$-ketoacyl synthase, beta subunit.

Similar polyketide skeletons are present in echinosporami$\operatorname{cin}^{18}$ and related molecules ${ }^{19}$ and in the polycyclic xanthone antibiotics, ${ }^{20}$ but with differences in the saturation degree and decoration of the aromatic rings. Like echinosporamicins, enduracyclinones present a 1,4-benzoquinone moiety (ring B), instead of the gamma-pyrone found in the polycyclic xanthones, and a second quinone (ring E), an uncommon feature of xanthones. Indeed, xantholipin is the only representative of this class with a quinone in ring $\mathrm{E}$, which is usually monooxygenated (as in cervinomycin and actinoplanone) or contains a para-biphenol (i.e., simaomycin and kibdelone). ${ }^{20}$ The three adjacent oxygens present in rings $\mathrm{C}$ and $\mathrm{D}$ of enduracyclinones are found only in some polycyclic xanthones (lysolipin I and FD-594), ${ }^{20}$ where ring D is 
nonaromatic, but not in echinosporamicins. Position C-4 is oxygenated in all xanthones ${ }^{20}$ and echinosporamicins ${ }^{19}$ but unmodified in $\mathbf{1}$ and 2, rendering the $A B C$ ring system of enduracyclinones identical to bequinostatin's, which however lacks the ring $\mathrm{C}$ methoxy and substantially differs in the remaining portion of the molecule. ${ }^{21}$

Most polycyclic xanthones and echinosporamicins present a cyclic amide (ring F), which can be substituted on the nitrogen with amine, methyl, or amino acid-derived heterocyclic structures. In particular, echinosporamicin carries a Gly-AlaSer tripeptide, ${ }^{18}$ with the serine condensed on the alanine to form a piperazinone moiety, whereas an oxazolidine ring is fused to the pyrimidone in cervinomycin. ${ }^{20}$ The unique feature of enduracyclinones is the presence of an $N$-methyl enduracididine moiety contributing to ring F. Enduracididine is an uncommon amino acid arising from arginine oxidization and cyclization and characterized by a guanidine embedded in a five-membered ring. Enduracididine has been so far encountered in a small number of natural products, where it can also be decorated with a $\beta$-hydroxy group. ${ }^{22}$ In most cases (enduracidin, mannopeptimycin, and teixobactin), enduracididine incorporation proceeds through a nonribosomal peptide synthase (NRPS) assembly line, whereas in minosaminomycin the enduracididine moiety is linked to an amino sugar through an amide bond and carbamoylated at its $\alpha$-nitrogen. Thus, enduracyclinones represent the first example of an enduracididine-containing aromatic polyketide and the first report of an $\mathrm{N}$-methylated enduracididine moiety and represent another example of actinomycetes' ability in performing combinatorial biosynthesis by joining different pathways for the generation of chemical diversity.

Enduracididine contains two stereogenic carbons that can occur in microbial metabolites in any R/S combination. ${ }^{22}$ The stereochemistry of the enduracididine moiety in $\mathbf{1}$ could not be established experimentally. Indeed, the amide bond linking enduracididine to the polyketide core is trapped in a pseudoaromatic ring, preventing easy release of this amino acid and direct comparison with suitable standards. The free rotation around the methylene in beta position (C-19) prevents using NMR data for relative stereochemistry assignment. As explained below, the enduracyclinone biosynthetic gene cluster (BGC) contains homologues of genes involved in Lenduracididine (i.e., 2S-4R-enduracididine) biosynthesis. ${ }^{23,24}$ Since the D-enduracididine isomers occurring in enduracidin and mannopeptimycin are reported to be generated by NRPScatalyzed epimerization at the $\alpha$-carbon ${ }^{23,25}$ and the enduracyclinone BGC does not apparently encode epimerases, it is reasonable to assume that the stereochemistry of the enduracididine moiety in $\mathbf{1}$ is $S$ and $R$ for the alpha (C18) and gamma (C20) carbons, respectively.

Putative Enduracyclinone Biosynthetic Gene Cluster. The structure of enduracyclinone suggested that it is generated from a (partially cyclized) tridecaketide intermediate condensed to an ( $N$-methyl)-enduracididine, followed by formation of ring F. Oxidation at C-5, C-13, and C-14 and the three $\mathrm{O}$ - methylations might precede or follow ring $\mathrm{F}$ formation. To search for the enduracyclinone BGC, we scanned a draft genome sequence of Nonomuraea sp. ID40491, using the antiSMASH platform (https://antismash.secondarymetabolites.org) for the presence of an aromatic polyketide gene cluster associated with genes specifying for Lenduracididine biosynthesis. The likely enduracyclinone $(e d c)$ cluster encompasses a $37 \mathrm{kbp}$ segment and includes 35 CDSs.
By bioinformatic analysis we could assign a putative role to almost all genes in the cluster and establish its likely boundaries, as depicted in Figure 4 and summarized in Table 2.

The biosynthesis of L-enduracididine has been established for the mannopeptimycin pathway; it involves MppP, a PLPdependent aminotransferase proposed to convert L-Arg into 2oxo-4-hydroxy-5-guanidinovaleric acid, which is then cyclized by MppR and transaminated by MppQ using L-Ala as amino donor. $^{24}$ Proteins showing $81 \%, 68 \%$, and $75 \%$ identity to $\mathrm{MppP}, \mathrm{MppQ}$ and $\mathrm{MppR}$, respectively, are encoded by a three-gene cassette (endPQR) in the enduracidine gene cluster. ${ }^{23}$ ORFs with $63-62 \%, 54-56 \%$, and $65-66 \%$ identity to $M p p P / E n d P, M p p Q / E n d Q$ and $M p p R / E n d R$, respectively, are present in the edc cluster, although only the former two genes are adjacent (Figure 4). The edc cluster encodes a protein (Chr_03773) with $50 \%$ identity to $\mathrm{PdmN}$, an asparagine synthase-like enzyme involved in the biosynthesis of pradimicin, a dodecaketide linked through an amide bond to an Ala residue. ${ }^{26}$ Thus, Chr_03773 is the likely amino acid ligase attaching ( $N$-methyl)enduracidin to a tridecapolyketide precursor.

Synthesis of the enduracyclinone carbon backbone is expected to require a type II PKS. Accordingly, the edc cluster encodes a ketosynthase, chain length factor (CLF), and acyl carrier protein, although the latter gene is not immediately downstream of the CLF-encoding gene (Figure 4 and Table 2 ). The $e d c$ cluster encodes also three polyketide cyclases, four monooxygenases, two methyltransferases, two oxidases, and a bifunctional cyclase-methyltransferase. The edc cluster also encodes a malonyl-CoA-generating system (the three components of a biotin-dependent carboxylase for generating the malonyl-CoA extender units), recently found also in the paramegnetoquinone gene cluster from Actinoallomurus. ${ }^{27}$ In addition, the cluster encodes five regulators, four transporters, and three proteins of unknown function (Figure 4 and Table 2 ). Final confirmation of the role of the described cluster in enduracyclinone biosynthesis should be obtained by genetic manipulation (e.g., by generation of knockout mutants or by heterologous expression), which was beyond the scope of our work. However, it would also be interesting to analyze the genomes of the other seven producers to check whether they contain the identified cluster.

Biological Activity of Enduracyclinones. Enduracyclinone A (1) showed good activity against staphylococci and streptococci, with MICs ranges of $0.0005-0.03$ and $0.25-0.5$ $\mu \mathrm{g} \mathrm{mL}{ }^{-1}$, respectively (Table 3 ). Activity was also observed against enterococci (MICs 2-4 $\mu \mathrm{g} \mathrm{mL}^{-1}$ ), Clostridium difficile $\left(2 \mu \mathrm{g} \mathrm{mL}^{-1}\right)$, and Propionibacterium acnes $\left(0.25 \mu \mathrm{g} \mathrm{mL}^{-1}\right)$. No activity was observed against Mycobacterium smegmatis, Gramnegative bacteria, or Candida albicans. Identical activity against S. aureus ATCC $6538 \mathrm{P}$ was obtained for purified compound 1 and for the mixture containing $\mathbf{1}$ and its des-methyl derivative in a 9:1 ratio, ruling out the possibility that the observed biological activity derived only from peak $\mathrm{A}^{\prime}$. As expected from its structural novelty, enduracyclinone A (1) was equally active against one strain each of $S$. aureus and of Staphylococcus hemolyticus with multiple resistance to clinically used antibiotics. Time-kill experiments with two different S. aureus strains indicated a rapid bactericidal activity, with $>99.9 \%$ killing within 2 to $4 \mathrm{~h}$ at $8 \times$ MIC. Longer incubations (i.e., 24 h) led to an increase in viable cell counts, comparable to untreated controls (Supplementary Figure S2). 
Table 3. Antibacterial Activity of Enduracyclinone A (1), Vancomycin (Van), and Gentamicin (Gen) expressed as MIC values

\begin{tabular}{|c|c|c|c|c|}
\hline \multirow[b]{2}{*}{$\operatorname{strain}^{a}$} & \multirow[b]{2}{*}{ resistance $^{b}$} & \multicolumn{3}{|c|}{$\operatorname{MIC}\left(\mu \mathrm{g} \mathrm{mL}^{-1}\right)$} \\
\hline & & 1 & Van & Gen \\
\hline $\begin{array}{l}\text { Staphylococcus aureus } \\
\text { ATCC } 6538 \mathrm{P}\end{array}$ & & 0.004 & 0.5 & 0.5 \\
\hline $\begin{array}{l}\text { Staphylococcus aureus } \\
\text { ATCC } 29213\end{array}$ & & 0.0005 & 1 & 0.5 \\
\hline $\begin{array}{l}\text { Staphylococcus aureus } \\
\text { L3864 }\end{array}$ & $\mathrm{Met}^{\mathrm{R}}$ & 0.03 & 1 & $>128$ \\
\hline $\begin{array}{l}\text { Staphylococcus aureus } \\
\text { L3797 }\end{array}$ & $\begin{array}{l}\mathrm{Met}^{\mathrm{R}}, \mathrm{AGs}^{\mathrm{R}}, \\
\mathrm{Cip}^{\mathrm{R}}, \mathrm{Cli}^{\mathrm{R}}, \\
\operatorname{Van}^{\mathrm{I}}\end{array}$ & 0.03 & 8 & 64 \\
\hline $\begin{array}{l}\text { Staphylococcus } \\
\text { hemolyticus L1730 }\end{array}$ & & 0.03 & 2 & $>128$ \\
\hline $\begin{array}{l}\text { Staphylococcus } \\
\text { hemolyticus L1729 }\end{array}$ & $\begin{array}{l}\mathrm{Met}^{\mathrm{R}} \mathrm{Tet}^{\mathrm{R}}, \\
\mathrm{AGs}^{\mathrm{R}}, \mathrm{Cip}^{\mathrm{R}}\end{array}$ & 0.015 & 2 & $>128$ \\
\hline $\begin{array}{l}\text { Staphylococcus } \\
\text { intermedius ATCC } \\
29663\end{array}$ & & 0.007 & 1 & $\leq 0.125$ \\
\hline $\begin{array}{l}\text { Streptococcus pyogenes } \\
\text { L49 }\end{array}$ & & 0.5 & 0.25 & 16 \\
\hline $\begin{array}{l}\text { Streptococcus pneumoniae } \\
\text { ATCC BAA1407 }\end{array}$ & ermB, mefE & 0.25 & 0.5 & 64 \\
\hline $\begin{array}{l}\text { Streptococcus pneumoniae } \\
\text { L44 }\end{array}$ & & 0.25 & 0.125 & 8 \\
\hline $\begin{array}{l}\text { Enterococcus faecium } \\
\text { L568 }\end{array}$ & & 4 & 1 & 32 \\
\hline $\begin{array}{l}\text { Enterococcus faecium } \\
\text { L569 }\end{array}$ & VanA & 2 & $>128$ & 16 \\
\hline $\begin{array}{l}\text { Propionibacterium acnes } \\
\text { ATCC } 25746\end{array}$ & & 0.25 & 0.25 & 2 \\
\hline $\begin{array}{l}\text { Clostridium difficile } \\
\text { ATCC } 17858\end{array}$ & & 2 & 0.5 & 128 \\
\hline
\end{tabular}

${ }^{a}$ Strains designated with an $\mathrm{L}$ prefix are clinical isolates (collected in Italy or USA) from the NAICONS collection. Other strains are from the American Type Culture Collection, USA. ${ }^{b}$ The superscript $\mathrm{R}$ indicates resistance to methicillin (Met), aminoglycosides (AGs), ciprofloxacin (Cip), clindamycin (Cli), or tetracyclin (Tet); the superscript I indicates intermediate resistance to vancomycin (Van); ermB and mefE indicate the known genetic determinants conferring resistance to macrolides-lincosamides-streptogramins by ribosomal methylation and to macrolides by efflux, respectively. VanA designates vancomycin-inducible resistance to glycopeptides by lipid II modification.

Comparably low MIC values vs Gram-positive bacteria have been reported for some structurally related compounds, such as lysolipin $\mathrm{I}^{28}$ cervinomycin, ${ }^{29}$ and echinosporamicins. ${ }^{19}$ It should be noted that several of these molecules exhibited cytotoxic activity to tumor cell lines at concentrations comparable to or lower than the MIC, ${ }^{20}$ e.g., actinoplanone, simaomicin, and xantholipin ${ }^{30-32}$ and echinosporamicinrelated compounds. ${ }^{19}$ When evaluated on the cancer cell line PANC-1 or the non-cancer cell line HEK-293, enduracyclinone A (1) showed only $20 \%$ inhibition at $90 \mu \mathrm{M}$ or an $\mathrm{IC}_{50}$ of $55 \mu \mathrm{M}$, respectively (Supplementary Figure S3). Thus, in comparison with the previously mentioned molecules, enduracyclinone A shows little cytotoxicity against the tested cell lines.

As mentioned above, the enduracyclinone-containing extracts were selected for their $\geq 8$-fold higher activity on WT $S$. aureus than on the corresponding L-form (Supplementary Table S1), indicating that peptidoglycan-devoid cells are less sensitive than the parental cells. When tested against Bacillus subtilis BAU102, a reporter strain that detects most classes of cell wall inhibitors, ${ }^{13}$ enduracyclinone A (1) elicited a signal compatible with cell wall inhibition and distinct from that caused by detergents (Supplementary Table S2). We then evaluated the effect of enduracyclinone A (1) on macromolecular synthesis in $S$. aureus, observing a dose-dependent inhibition of DNA and cell wall biosynthesis, with comparable $\mathrm{IC}_{50}$ values ( 2 and $5 \mu \mathrm{g} \mathrm{mL}{ }^{-1}$, respectively). While RNA synthesis was only marginally affected, incorporation of label into proteins appeared to be stimulated by enduracyclinone A (Supplementary Figure S4).

Overall, the results from the L-form assay, the reporter assay, and macromolecular syntheses are consistent with inhibition of cell wall biosynthesis by enduracyclinone A, although DNA synthesis is also likely to be affected. There are few reports on the mechanism of action of structurally related molecules. Lysolipin has been proposed to target bactoprenol-containing molecules and inhibit cell wall biosynthesis, based on inhibition of peptidoglycan synthesis and concomitant accumulation of lipid-bound precursors in B. subtilis. ${ }^{28}$ On the basis of its effect on macromolecular syntheses, solute leakage, and reversion assays in $S$. aureus, cervinomycin has been proposed to interfere with membrane functions by interaction with phospholipids. ${ }^{33}$ Inhibition of DNA synthesis, interference with cell cycle regulation, or generation of reactive oxygen species was proposed for the cytotoxic effects of different polycyclic xanthones. ${ }^{30,31,34}$ Interestingly, while minosaminomycin (structurally similar to the aminoglycoside kasugamycin) interferes with initiation of protein synthesis, ${ }^{35}$ the other enduracididine-containing antibiotics (teixobactin, enduracidine, and mannopeptimycin) inhibit cell wall biosynthesis by binding to lipid II. ${ }^{36}$ Thus, it is tempting to speculate that appending a positively charged, rigid amino acid on a flat, hydrophobic skeleton might enhance affinity for cell wall intermediates, endowing enduracyclinone A with a dual mechanism of action.

These potent antibacterial compounds, produced at high levels by at least three different Nonomuraea lineages, had so far apparently escaped detection. This bodes well for discovering new classes of antibacterial agents from actinomycetes.

\section{EXPERIMENTAL SECTION}

General Experimental Procedures. ${ }^{1} \mathrm{H}$ and ${ }^{13} \mathrm{C} 1 \mathrm{D}$ and $2 \mathrm{D}$ NMR spectra (COSY, TOCSY, NOESY, HSQC, HMBC, ${ }^{13} \mathrm{C}-{ }^{13} \mathrm{C}$ COSY, ${ }^{1} \mathrm{H}-{ }^{15} \mathrm{~N}-\mathrm{HSQC},{ }^{1} \mathrm{H}-{ }^{15} \mathrm{~N}-\mathrm{HMBC}$ ) were measured in DMSO$d_{6}$ at $25{ }^{\circ} \mathrm{C}$ using a Bruker Avance II $300 \mathrm{MHz}$ spectrometer. The ${ }^{13} \mathrm{C}$ NMR spectrum of compound $\mathbf{1}$ was acquired on an Agilent (Varian) VNMRS $500 \mathrm{MHz}$ spectrometer. LC-MS analyses were performed with a Dionex UltiMate 3000 (Thermo Scientific) coupled with an LCQ Fleet mass spectrometer equipped with an electrospray interface (ESI) and a tridimensional ion trap. The column was an Atlantis T3 C18 $5 \mu \mathrm{m} \times 4.6 \mathrm{~mm} \times 50 \mathrm{~mm}$ maintained at $40{ }^{\circ} \mathrm{C}$ at a flow rate of $0.8 \mathrm{~mL} \mathrm{~min}{ }^{-1}$. Phases $\mathrm{A}$ and $\mathrm{B}$ were $0.05 \% \mathrm{TFA}$ and $\mathrm{MeCN}$, respectively. The gradient was $10 \%, 10 \%, 95 \%, 95 \%$, and $10 \%$ phase $\mathrm{B}$ at $0,1,7,9$, and $10 \mathrm{~min}$, respectively. UV-vis signals $(190-600 \mathrm{~nm})$ were acquired using a diode array detector. The $\mathrm{m} / z$ range was $110-$ 2000 , and the ESI conditions were as follows: spray voltage of $3500 \mathrm{~V}$, capillary temperature of $275^{\circ} \mathrm{C}$, sheath gas flow rate at $35 \mathrm{~mL} \mathrm{~min}{ }^{-1}$, and auxiliary gas flow rate at $15 \mathrm{~mL} \mathrm{~min}{ }^{-1}$. HR-MS analyses were performed as a service by the Department of Pharmaceutical Sciences, University of Milan, Italy. HPLC analyses were carried out using a Shimadzu LC-2010AHT equipped with a Merck LiChrosphere 100 RP18 LiChroCART column, $5 \mu \mathrm{m}(125 \times 4 \mathrm{~mm})$ with detection at $280 \mathrm{~nm}$ and oven temperature at $50{ }^{\circ} \mathrm{C}$. Flow rate set at $1 \mathrm{~mL} \mathrm{~min}{ }^{-1}$. Phases $\mathrm{A}$ and $\mathrm{B}$ were $0.1 \% \mathrm{TFA}$ and $\mathrm{MeCN}$, respectively. The 
gradient used was $10 \%, 45 \%, 70 \%$, and $90 \%$ phase B at $0,5,15$, and 17 min, respectively.

Actinomycete Strains and Growth Conditions. Strains were maintained as frozen cultures at $-80{ }^{\circ} \mathrm{C}$ in the NAICONS strain library. They were cultivated on $\mathrm{S} 1$ plates ${ }^{10}$ at $30^{\circ} \mathrm{C}$. All Erlenmeyer flasks used for liquid cultures had one baffle. For production of enduracyclinones the microbial content of one S1 plate was scraped and inoculated into $50 \mathrm{~mL}$ Erlenmeyer flasks containing $10 \mathrm{~mL}$ of medium $\mathrm{AF}$ (dextrose monohydrate $20 \mathrm{~g} \mathrm{~L}^{-1}$, yeast extract $2 \mathrm{~g} \mathrm{~L}^{-1}$, soybean meal $8 \mathrm{~g} \mathrm{~L}^{-1}, \mathrm{NaCl} 1 \mathrm{~g} \mathrm{~L}^{-1}$, and $\mathrm{CaCO}_{3} \mathrm{~g} \mathrm{~L}^{-1}, \mathrm{pH}$ 7.3). The strains were grown at $30^{\circ} \mathrm{C}$ on an orbital shaker at $200 \mathrm{rpm}$. After 72 h, $5 \mathrm{~mL}$ of the culture was transferred into $500 \mathrm{~mL}$ Erlenmeyer flasks containing $100 \mathrm{~mL}$ of fresh AF medium. After a further $72 \mathrm{~h}$ cultivation as above, a $5 \%$ inoculum was made into $100 \mathrm{~mL}$ of medium INA5 (glycerol $30 \mathrm{~g} \mathrm{~L}^{-1}$, soybean meal $15 \mathrm{~g} \mathrm{~L}^{-1}, \mathrm{CaCO}_{3} 5 \mathrm{~g}$ $\left.\mathrm{L}^{-1}, \mathrm{NaCl} 2 \mathrm{~g} \mathrm{~L}^{-1}, \mathrm{pH} 7.2\right)$ in $500 \mathrm{~mL}$ Erlenmeyer flasks, which were incubated for $168 \mathrm{~h}$ under the same conditions described above.

Isotope Labeling. $\mathrm{NM}$ medium was ammonium sulfate $1.8 \mathrm{~g} \mathrm{~L}^{-1}$, $\mathrm{KH}_{2} \mathrm{PO}_{4} 0.15 \mathrm{~g} \mathrm{~L}^{-1}, \mathrm{MgSO}_{4} \cdot 7 \mathrm{H}_{2} \mathrm{O} 0.22 \mathrm{~g} \mathrm{~L}^{-1}$, TMS $3 \mathrm{~mL} \mathrm{~L}^{-1}$, vitamin solution $1 \mathrm{~mL} \mathrm{~L}^{-1}$, and $0.5 \mathrm{M}$ TES $\mathrm{pH} 7.540 \mathrm{~mL} \mathrm{~L}^{-1}$. [TMS consists of $\left(\mathrm{g} \mathrm{L}^{-1}\right) \mathrm{FeSO}_{4} \cdot 7 \mathrm{H}_{2} \mathrm{O} 5, \mathrm{CuSO}_{4} \cdot 5 \mathrm{H}_{2} \mathrm{O} 0.39, \mathrm{ZnSO}_{4} \cdot 7 \mathrm{H}_{2} \mathrm{O}$ $0.44, \mathrm{MnCl}_{2} \cdot 4 \mathrm{H}_{2} \mathrm{O} 0.176, \mathrm{NaMoO}_{4} \cdot 2 \mathrm{H}_{2} \mathrm{O} 0.011, \mathrm{CuCl}_{2} \cdot 2 \mathrm{H}_{2} \mathrm{O} 0.02$; and $50 \mathrm{~mL} \mathrm{HCl} 37 \%$; vitamin solution consists of $\left(\mathrm{g} \mathrm{L}^{-1}\right)$ biotin 0.05 , Ca pantothenate 1, nicotinic acid 1, myo-inositol 25 , thiamine $\mathrm{HCl} 1$, pyridoxine $\mathrm{HCl} 1$; it was sterilized through a $0.22 \mu \mathrm{m}$ pore filter and added to the autoclaved medium.] Strain ID40491 from a frozen stock was inoculated $(5 \%)$ in $50 \mathrm{~mL}$ flasks containing $15 \mathrm{~mL}$ of $\mathrm{NM}$ medium supplemented with $10 \%$ glycerol and cultivated $72 \mathrm{~h}$ as above. Then, $12 \mathrm{~mL}$ of the culture was washed twice with $12 \mathrm{~mL}$ of medium NM (by centrifugation and resuspension), and $6 \mathrm{~mL}$ of the resuspended mycelium was used to inoculate $100 \mathrm{~mL}$ of NM medium supplemented with $1 \mathrm{~g} \mathrm{~L}^{-1}$ Celtone base powder $\left(>98 \%{ }^{13} \mathrm{C}\right.$ - and $>98 \%{ }^{15} \mathrm{~N}$-labeled, Cambridge Isotope Laboratories). The strain was cultured under the conditions described above for $120 \mathrm{~h}$ before metabolite extraction. The average enrichment was calculated using LC-MS analysis (Supplementary Figure S1), which showed a maximum $\mathrm{m} / z$ signal of $749[\mathrm{M}+\mathrm{H}]^{+}$with an increment of 38 amu with respect to the unlabeled compound. A full labeled compound 1 is expected to have an $m / z 751[\mathrm{M}+\mathrm{H}]^{+}$; thus the enrichment was calculated as $95 \%$.

Metabolite Extraction and Purification. For purification of enduracyclinones, a $600 \mathrm{~mL}$ culture was centrifuged ( $10 \mathrm{~min}$ at 1800 rcf), and the resulting mycelium and cleared broth were processed separately. The mycelium was resuspended in water $(200 \mathrm{~mL}$ final volume) and, after adjusting the $\mathrm{pH}$ from 7.9 to 9.7 with $0.5 \mathrm{~N} \mathrm{NaOH}$ and adding $200 \mathrm{~mL}$ of $\mathrm{EtOH}$, shaken for $20 \mathrm{~min}$ at RT. After centrifugation ( $5 \mathrm{~min}$ at $1800 \mathrm{rcf}$ ), the supernatant was recovered and dried under vacuum. For processing the cleared broth, the $\mathrm{pH}$ was adjusted from 7.5 to 5 with $1 \mathrm{~N} \mathrm{HCl}$, which led to product precipitation. The pellet was recovered by centrifugation $(10 \mathrm{~min}$ at $3200 \mathrm{rcf}$ ) and resuspended in $60 \mathrm{~mL}$ of water. After adjusting the $\mathrm{pH}$ to 9.5 with $0.5 \mathrm{~N} \mathrm{NaOH}$ and adding $60 \mathrm{~mL}$ of $\mathrm{EtOH}$, residual debris was removed by centrifugation $(10 \mathrm{~min}$ at $1800 \mathrm{rcf}$ ) and the solvent from the resulting supernatant was removed under reduced pressure.

The crude extracts from mycelium and cleared broth were separately purified on a CombiFlash RF (Teledyne ISCO) mediumpressure chromatography system on a $30 \mathrm{~g}$ Biotage SNAP Cartridge

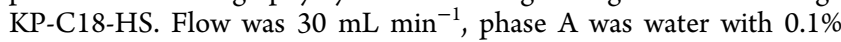
TFA, and phase B was acetonitrile. The column was previously conditioned at $5 \%$ phase B, gradient to $40 \%$ phase B in 2 min, and then $60 \%$ phase B in $25 \mathrm{~min}$. Fractions with similar purity were pooled and dried under vacuum, yielding $90 \mathrm{mg}$ of a dark red powder containing compounds 1 and des-methyl-1 in a 9:1 ratio. This powder was used for NMR characterization and for nearly all bioactivity studies. From the same chromatography, an additional $35 \mathrm{mg}$ sample was collected containing compounds $\mathbf{1}, 2$, and des-methyl $\mathbf{1}$ in a 5:3:2 ratio. A $2 \mathrm{mg}$ amount of the 9:1 ratio powder was further purified using an LC 2010A-HT liquid chromatography instrument (Shimadzu Corporation) equipped with a LiChrosphere C18 $5 \mu \mathrm{m}$, $4.6 \mathrm{~mm} \times 100 \mathrm{~mm}$ column (Merck). Elution was performed at $1 \mathrm{~mL}$ $\min ^{-1}, 50{ }^{\circ} \mathrm{C}$ with a multistep program set as follows: $10 \%, 45 \%, 70 \%$, $90 \%, 90 \%, 10 \%$, and $10 \%$ phase B at $0,15,17,20,21$, and $29 \mathrm{~min}$, respectively. Phase A was $0.1 \%$ TFA (v/v) in $\mathrm{H}_{2} \mathrm{O}$, and phase $\mathrm{B}$ was $\mathrm{CH}_{3} \mathrm{CN}$. UV detection was set at 270 and $420 \mathrm{~nm}$. About $450 \mu \mathrm{g}$ of purified compound $\mathbf{1}$ (enduracyclinone A) was collected and used for MIC evaluation on S. aureus ATCC 6538P.

For purification of the labeled compounds, $20 \mathrm{~mL}$ of $0.5 \mathrm{M}$ ammonium acetate $(\mathrm{pH} 8.8)$ and $110 \mathrm{~mL}$ of EtOH were added to a $200 \mathrm{~mL}$ culture, and the suspension was shaken $1 \mathrm{~h}$ at RT. After centrifugation ( $10 \mathrm{~min} 1800 \mathrm{rcf}$ ), the supernatant was recovered, partially concentrated under vacuum to remove $\mathrm{EtOH}$, and acidified to $\mathrm{pH} 4-4.5$ with $1 \mathrm{~N} \mathrm{HCl}$. Under these conditions enduracyclinones form a dark red precipitate, which was collected by centrifugation (10 min $1800 \mathrm{rcf}$ ) and dried under vacuum, obtaining $5 \mathrm{mg}$ of $95 \%$ labeled compounds $\mathbf{1}$ and des-methyl-1 in a 9:1 ratio.

Enduracyclinone A, 1: HPLC $t_{\mathrm{R}} 9.5 \mathrm{~min}$; LC-MS $t_{\mathrm{R}} 5.93 \mathrm{~min} \mathrm{UV}-$ vis $(0.1 \% \mathrm{TFA} / \mathrm{MeCN}, 1: 1) \lambda_{\max } 234,283,334$, and $445 \mathrm{~nm} ;{ }^{1} \mathrm{H}$ and ${ }^{13} \mathrm{C}$ NMR data, Table 1; ESI(+)MS $m / z 711.2[\mathrm{M}+\mathrm{H}]^{+}$; HRESI(+) MS $m / z 711.1942[\mathrm{M}+\mathrm{H}]^{+}$(calcd for $\mathrm{C}_{36} \mathrm{H}_{30} \mathrm{~N}_{4} \mathrm{O}_{12} 711.1938$ ).

Enduracyclinone B, 2: HPLC $t_{\mathrm{R}} 12 \mathrm{~min}$; LC-MS $t_{\mathrm{R}} 6.02 \mathrm{~min} \mathrm{UV}-$ vis $(0.1 \% \mathrm{TFA} / \mathrm{MeCN}, 1: 1) \lambda_{\max } 241,295$, and $425 \mathrm{~nm}$; $\mathrm{ESI}(+) \mathrm{MS}$ $m / z 713.2[\mathrm{M}+\mathrm{H}]^{+}$; HRESI $(+)$MS $m / z 713.2104[\mathrm{M}+\mathrm{H}]^{+}(\mathrm{calcd}$ for $\mathrm{C}_{36} \mathrm{H}_{32} \mathrm{~N}_{4} \mathrm{O}_{12} 713.2095$ ).

Des-methyl Enduracyclinone A: HPLC $t_{\mathrm{R}} 10 \mathrm{~min}$; LC-MS $t_{\mathrm{R}} 6.48$ $\min$ UV-vis $(0.1 \% \mathrm{TFA} / \mathrm{MeCN}, 1: 1) \lambda_{\max } 237,287,340$, and 470 $\mathrm{nm}$; ESI(+)MS $m / z 697.2[\mathrm{M}+\mathrm{H}]^{+}$; HRESI(+) MS $m / z 697.1786$ $[\mathrm{M}+\mathrm{H}]^{+}$(calcd for $\mathrm{C}_{35} \mathrm{H}_{28} \mathrm{~N}_{4} \mathrm{O}_{12} 697.1776$ ).

Chemical Modifications. Reactions were performed on a sample containing 1 and its des-methyl derivative in a 9:1 ratio (designated 1 for simplicity), unless stated otherwise. Amidation: Compound 1 (2 $\mathrm{mg}$ ) was dissolved in $400 \mu \mathrm{L}$ of DMF, and $2 \mu \mathrm{L}$ of $N, N$ dimethylpropylamine was added adjusting the $\mathrm{pH}$ to 8 . After adding $2 \mathrm{mg}$ of PyBOP, the mixture was stirred for $1 \mathrm{~h}$ at RT. LC-MS analysis showed the disappearance of compound $1\left(t_{\mathrm{R}} 5.90 \mathrm{~min}\right)$ and the formation of the corresponding amide $\left(t_{\mathrm{R}} 4.57 \mathrm{~min}, \mathrm{~m} / z\right.$ 795.2 $[\mathrm{M}+$ $\mathrm{H}]^{+}$and $398[\mathrm{M}+2 \mathrm{H}]^{2+}$ and $\lambda_{\max }$ at 245,285 , and $\left.539 \mathrm{~nm}\right)$, along with the formation of des-methyl- 1 corresponding amide $\left(t_{\mathrm{R}} 4.60 \mathrm{~min}\right.$, $m / z 781.1[\mathrm{M}+\mathrm{H}]^{+}$and $391[\mathrm{M}+2 \mathrm{H}]^{2+}$ and $\lambda_{\max }$ at 247,292 , and $537 \mathrm{~nm})$. Methylation: To a solution of $1(1 \mathrm{mg})$ in $100 \mu \mathrm{L}$ of $\mathrm{MeOH}$, was added $4 \mu \mathrm{L}$ of $2 \mathrm{M}$ trimethylsylyldiazomethane in diethyl ether, and the solution stirred at RT for $5 \mathrm{~h}$. LC-MS analysis showed the disappearance of 1 and formation of one peak at $6.18 \mathrm{~min}$ with $\mathrm{m} /$ $z 725.2[\mathrm{M}+\mathrm{H}]^{+}$and $\lambda_{\max }$ at $235,284,336$, and $440 \mathrm{~nm}$, and a second peak at $6.28 \mathrm{~min}$ with $m / z 711.3[\mathrm{M}+\mathrm{H}]^{+}$and $\lambda_{\max }$ at 243 , 288 , and $432 \mathrm{~nm}$, corresponding to the methyl esters of 1 and of desmethyl-1, respectively. Oxidation: Compounds 1, 2, and des-methyl-1 ( $2 \mathrm{mg}$, in a 5:3:2 ratio) were dissolved in $2.5 \mathrm{~mL}$ of $\mathrm{MeCN} / \mathrm{H}_{2} \mathrm{O}$ (1:1), and $175 \mu \mathrm{L}$ of $30 \% \mathrm{H}_{2} \mathrm{O}_{2}$ was added. After $24 \mathrm{~h}$ at RT, LC-MS analysis showed the conversion of compound 2 into 1 . Quinone cleavage: Compound $1(1 \mathrm{mg})$ was dissolved in $50 \mu \mathrm{L}$ of $\mathrm{MeCN} /$ $\mathrm{H}_{2} \mathrm{O}(1: 1)$, and $100 \mu \mathrm{L}$ of $30 \% \mathrm{H}_{2} \mathrm{O}_{2}$ was added. The mixture was heated to $60{ }^{\circ} \mathrm{C}$, and the reaction monitored by LC-MS, which showed the formations of peaks at 5.15, 6.30, and $6.72 \mathrm{~min}$ corresponding to $m / z[M+\mathrm{H}]^{+}$values of 637.0 (ox-1, $\lambda_{\max }$ at 234, 313 , and $420 \mathrm{~nm}$ ), 469.1 (ox-2,major species; $\lambda_{\max }$ at 246,300 , and $430 \mathrm{~nm}$ ), 455.1 (des-methyl-ox-2, minor species), and 279.2 (ox-3, $\lambda_{\max }$ at $\left.300 \mathrm{~nm}\right)$, respectively.

Biological Assays. All tests were performed on a sample containing 1 and its des-methyl derivative in a 9:1 ratio. MIC for $S$. aureus ATCC $6538 \mathrm{P}$ was determined also for the purified compound 1. Antimicrobial activity of extracts was evaluated by agar diffusion, using extracts obtained by centrifuging (10 min $1800 \mathrm{rcf}$ ) a $10 \mathrm{~mL}$ culture and extracting the resulting mycelium with $4 \mathrm{~mL}$ of EtOH for $1 \mathrm{~h}$ at RT with shaking. The EtOH extracts $(200 \mu \mathrm{L}$, corresponding to $0.5 \mathrm{~mL}$ of culture) were dried under vacuum and dissolved in $100 \mu \mathrm{L}$ of $10 \% \mathrm{DMSO}$, and $10 \mu \mathrm{L}$ was then deposited on $30 \mathrm{~mL}$ of MuellerHinton agar in a $14.5 \mathrm{~mm}$ diameter plate inoculated with $10^{5} \mathrm{CFU} /$ $\mathrm{mL}$ S. aureus ATCC $6538 \mathrm{P}$ or L3797, scoring the presence of growth inhibition halos after $16 \mathrm{~h}$ at $37{ }^{\circ} \mathrm{C}$. Determination of minimal inhibitory concentrations (MIC) was performed as previously 
described. ${ }^{10}$ Time-kill experiments were performed following a previously described procedure. ${ }^{11}$ The conditions for using Bacillus subtilis BAU102 to detect cell wall inhibitors or detergents have been previously described. ${ }^{13}$

Effect on Macromolecular Syntheses. The effect on macromolecular synthesis was tested by monitoring the incorporation of labeled precursors $\left(5-\left[{ }^{3} \mathrm{H}\right]\right.$ thymidine for DNA, $\left[{ }^{3} \mathrm{H}\right]$ uridine for RNA, $\mathrm{L}-\left[{ }^{3} \mathrm{H}\right]$ tryptophan for protein and $\left[{ }^{3} \mathrm{H}\right]$ glucosamine hydrochloride for cell wall synthesis). S. aureus $12 \mathrm{ST}$ clinical isolate (P.L. proprietary collection) was grown overnight in $0.2 \times \mathrm{LB}\left(2 \mathrm{~g} \mathrm{~L}^{-1}\right.$ peptone, $1 \mathrm{~g} \mathrm{~L}^{-1}$ yeast extract, and $2 \mathrm{~g} \mathrm{~L}^{-1} \mathrm{NaCl}$ ), then diluted 200 -fold into the same medium, and grown at $37{ }^{\circ} \mathrm{C}$ to an $\mathrm{OD}_{600}$ of $0.2-0.25$. This medium can support fast growth while allowing efficient incorporation of labeled precursors (P.L., unpublished data). Cultures were split into four subcultures $(80 \mu \mathrm{L})$ and added to Eppendorf tubes containing either $10 \mu \mathrm{L}$ of medium (control) or $10 \mu \mathrm{L}$ of 1 at 10 -fold the final concentrations. After $5 \mathrm{~min}$ incubation at $37{ }^{\circ} \mathrm{C}, 10 \mu \mathrm{L}$ of radioactively labeled precursors (PerkinElmer), previously diluted to $0.1 \mu \mathrm{Ci} \mu \mathrm{L}^{-1}(1: 10)$, was added as follows: [6- $\left.{ }^{3} \mathrm{H}\right]$-thymidine, 0.15 $\mu \mathrm{Ci} /$ sample; $\left[5,6-{ }^{3} \mathrm{H}\right]$-uridine, $0.15 \mu \mathrm{Ci} /$ sample; L- $\left[5-{ }^{3} \mathrm{H}(\mathrm{N})\right]$-tryptophan, $0.25 \mu \mathrm{Ci} /$ sample; D-[6- $\left.{ }^{3} \mathrm{H}(\mathrm{N})\right]$-glucosamine hydrochloride, 0.4 $\mu \mathrm{Ci} /$ sample. Samples were incubated for a further $5 \mathrm{~min}$ at $37^{\circ} \mathrm{C}$; incorporation was stopped and macromolecules were precipitated by adding $0.9 \mathrm{~mL}$ of ice-cold 5\% trichloroacetic acid (TCA) and incubated for at least $30 \mathrm{~min}$ on ice before being filtered through glass microfiber filters (GF/C, Whatman). Filters were washed with $5 \mathrm{~mL}$ of TCA (5\%), dried, and counted in a Tricarb 2100 TR liquid scintillation analyzer (PerkinElmer) using the Ultima Gold scintillation cocktail (PerkinElmer). 1 was dissolved at $10 \mathrm{mg} \mathrm{mL}^{-1}$ in 50\% DMSO immediately prior to use, and subsequent dilutions were made in $0.2 \times$ LB. Maximal DMSO concentrations used in the experiment were $0.5 \%$, which did not affect either bacterial growth or incorporation of labeled markers, as tested in preliminary experiments. As controls for macromolecular synthesis inhibition, we used antibiotics with known mechanisms of action, namely, nalidixc acid $(25 \mu \mathrm{g} / \mathrm{mL})$ for DNA synthesis, rifampicin $(2 \mu \mathrm{g} / \mathrm{mL})$ for $\mathrm{RNA}$ synthesis, chloramphenicol $(20 \mu \mathrm{g} / \mathrm{mL})$ for protein synthesis, and vancomycin $(1 \mu \mathrm{g} / \mathrm{mL})$ for cell wall synthesis. In the experimental conditions used, these compounds totally and selectively inhibited their target macromolecular synthesis (data not shown).

DNA Sequences. DNA extraction, sequencing, and analysis of the $16 \mathrm{~S}$ rRNA gene were performed following published procedures. ${ }^{38} \mathrm{~A}$ draft genome sequence of Nonomuraea ID40491 was generated through Illumina technology by Microbial Genomics and Biotechnology Center for Biotechnology (Universität Bielefeld, Germany). Identification of the biosynthetic gene cluster was performed using the antiSMASH v3.0.1 tool at the default conditions. ${ }^{39}$

Accession Codes. The DNA sequences of the 16S rRNA genes and putative enduracyclinone gene cluster have been deposited in GenBank with accession numbers MF359959-MF359965 (Supplementary Table S2) and MG386284, respectively.

\section{ASSOCIATED CONTENT}

\section{S Supporting Information}

The Supporting Information is available free of charge on the ACS Publications website at DOI: 10.1021/acs.jnatprod.8b00354.

Experimental Section; characteristics of enduracyclinone-producing strains; reporter gene induction assay; time-kill data; cytotoxicity data; macromolecular syntheses inhibition data; ${ }^{13} \mathrm{C}-{ }^{15} \mathrm{~N}$ enrichment data; NMR spectra (PDF)

\section{AUTHOR INFORMATION}

\section{Corresponding Author}

*E-mail: pmonciardini@naicons.com. Phone: +3902 56660231.
ORCID 웅

Paolo Monciardini: 0000-0002-8727-2791

Marianna Iorio: 0000-0001-8669-5875

\section{Author Contributions}

"P. Monciardini and A. Bernasconi contributed equally to this work.

\section{Notes}

The authors declare the following competing financial interest(s): P.M., A.B., M.I., C.B., M.S., S.M., and S.D. are employees and/or shareholders of NAICONS and/or KtedoGen.

\section{ACKNOWLEDGMENTS}

This work received support from the European Commission's Horizon 2020 programme under grant agreement 664588 (NOMORFILM project) and from MiUR-Regione Lombardia. We thank I. Biunno and M. Cattaneo (IRGB-CNR, Milan) for the cytotoxicity test, H.-G. Sahl (University of Bonn) for helpful advice, and R. Fattori (IFOM, Milan) for $1 \mathrm{D}-{ }^{13} \mathrm{C}$ NMR experiment.

\section{REFERENCES}

(1) Moloney, M. G. Trends Pharmacol. Sci. 2016, 37, 689-701.

(2) Brown, E. D.; Wright, G. D. Nature 2016, 529, 336-343.

(3) Bumann, D. Curr. Opin. Microbiol. 2008, 11, 387-392.

(4) Demain, A. L. J. Ind. Microbiol. Biotechnol. 2014, 41, 185-201.

(5) Newman, D. J.; Cragg, G. M. J. Nat. Prod. 2012, 75, 311-335.

(6) Ling, L. L.; Schneider, T.; Peoples, A. J.; Spoering, A. L.; Engels, I.; Conlon, B. P.; Mueller, A.; Schaberle, T. F.; Hughes, D. E.; Epstein, S.; Jones, M.; Lazarides, L.; Steadman, V. A.; Cohen, D. R.; Felix, C. R.; Fetterman, K. A.; Millet, W. P.; Nitti, A. G.; Zullo, A. M.; Chen, C.; Lewis, K. Nature 2015, 517, 455-459.

(7) Maffioli, S. I.; Zhang, Y.; Degen, D.; Carzaniga, T.; Del Gatto, G.; Serina, S.; Monciardini, P.; Mazzetti, C.; Guglierame, P.; Candiani, G.; Chiriac, A. I.; Facchetti, G.; Kaltofen, P.; Sahl, H. G.; Dehò, G.; Donadio, S.; Ebright, R. H. Cell 2017, 169, 1240-1248e1223.

(8) Monciardini, P.; Iorio, M.; Maffioli, S.; Sosio, M.; Donadio, S. Microb. Biotechnol. 2014, 7, 209-220.

(9) Jabes, D.; Donadio, S. Methods Mol. Biol. 2010, 618, 31-45.

(10) Simone, M.; Monciardini, P.; Gaspari, E.; Donadio, S.; Maffioli, S. I. J. Antibiot. 2013, 66, 73-78.

(11) Maffioli, S. I.; Monciardini, P.; Catacchio, B.; Mazzetti, C.; Münch, D.; Brunati, C.; Sahl, H. G.; Donadio, S. ACS Chem. Biol. 2015, 10, 1034-1042.

(12) Iorio, M.; Sasso, O.; Maffioli, S. I.; Bertorelli, R.; Monciardini, P.; Sosio, M.; Bonezzi, F.; Summa, M.; Brunati, C.; Bordoni, R.; Corti, G.; Tarozzo, G.; Piomelli, D.; Reggiani, A.; Donadio, S. ACS Chem. Biol. 2014, 9, 398-404.

(13) De Pascale, G.; Grigoriadou, C.; Losi, D.; Ciciliato, I.; Sosio, M.; Donadio, S. J. Appl. Microbiol. 2007, 103, 133-140.

(14) Gerber, N. N.; Lechevalier, M. P. Can. J. Chem. 1984, 62, $2818-2821$.

(15) Rickards, R. W. J. Antibiot. 1989, 42, 336-339.

(16) Ogawa, H.; Natori, S. Chem. Pharm. Bull. 1968, 16, 17091720.

(17) Cameron, D. W.; Cromartie, R. I. T.; Kingston, D. G. I.; Todd, L. J. Chem. Soc. 1964, 0, 51-61.

(18) He, H.; Yang, H. Y.; Luckman, S. W.; Bernan, V. S.; Tsai, G.; Roll, D. M.; Carter, G. T. Helv. Chim. Acta 2004, 87, 1385-1391.

(19) Banskota, A. H.; Aouidate, M.; Sørensen, D.; Ibrahim, A.; Piraee, M.; Zazopoulos, E.; Alarco, A. M.; Gourdeau, H.; Mellon, C.; Farnet, C. M.; Falardeau, P.; McAlpine, J. B. J. Antibiot. 2009, 62, $565-570$.

(20) Winter, D. K.; Sloman, D. L.; Porco, J. A. Nat. Prod. Rep. 2013, $30,382-391$. 
(21) Aoyama, T.; Kojima, F.; Abe, F.; Muraoka, Y.; Naganawa, H.; Takeuchi, T.; Aoyagi, T. J. Antibiot. 1993, 46, 914-920.

(22) Atkinson, D. J.; Naysmith, B. J.; Furkert, D. P.; Brimble, M. A. Beilstein J. Org. Chem. 2016, 12, 2325-2342.

(23) Yin, X.; Zabriskie, T. M. Microbiology 2006, 152, 2969-2983.

(24) Han, L.; Schwabacher, A. W.; Moran, G. R.; Silvaggi, N. R. Biochemistry 2015, 54, 7029-7040.

(25) Magarvey, N. A.; Haltli, B.; He, M.; Greenstein, M.; Hucul, J. A. Antimicrob. Agents Chemother. 2006, 50, 2167-2177.

(26) Zhan, J.; Qiao, K.; Tang, Y. ChemBioChem 2009, 10, 14471452.

(27) Iorio, M.; Cruz, J.; Simone, M.; Bernasconi, A.; Brunati, C.; Sosio, M.; Donadio, S.; Maffioli, S. I. J. Nat. Prod. 2017, 80, 819-827.

(28) Drautz, H.; Keller-Schierlein, W.; Zähner, H. Arch. Microbiol. 1975, 106, 175-190.

(29) Nakagawa, A.; Iwai, Y.; Shimizu, H.; Omura, S. J. Antibiot. 1986, 39, 1636-1638.

(30) Kobayashi, K.; Nishino, C.; Ohya, J.; Sato, S.; Mikawa, T.; Shiobara, Y.; Kodama, M. J. Antibiot. 1988, 41, 741-750.

(31) Koizumi, Y.; Tomoda, H.; Kumagai, A.; Zhou, X. P.; Koyota, S.; Sugiyama, T. Cancer Sci. 2009, 100, 322-326.

(32) Zhang, W.; Wang, L.; Kong, L.; Wang, T.; Chu, Y.; Deng, Z.; You, D. Chem. Biol. 2012, 19, 422-432.

(33) Tanaka, H.; Kawakita, K.; Suzuki, H.; Spiri-Nakagawa, P.; Omura, S. J. Antibiot. 1989, 42, 431-439.

(34) Liu, L. L.; He, L. S.; Xu, Y.; Han, Z.; Li, Y. X.; Zhong, J. L.; Guo, X. R.; Zhang, X. X.; Ko, K. M.; Qian, P. Y. Chem. Res. Toxicol. 2013, 26, 1055-1063.

(35) Suzukake, K.; Hori, M. J. Antibiot. 1977, 30, 132-140.

(36) Müller, A.; Klöckner, A.; Schneider, T. Nat. Prod. Rep. 2017, 34, 909-932.

(37) Medema, M. H.; Kottmann, R.; Yilmaz, P.; Cummings, M.; Biggins, J. B.; Blin, K.; de Bruijn, I.; Chooi, Y. H.; Claesen, J.; Coates, R. C.; Cruz-Morales, P.; Duddela, S.; Düsterhus, S.; Edwards, D. J.; Fewer, D. P.; Garg, N.; Geiger, C.; Gomez-Escribano, J. P.; Greule, A.; Hadjithomas, M.; Haines, A. S.; Helfrich, E. J.; Hillwig, M. L.; Ishida, K.; Jones, A. C.; Jones, C. S.; Jungmann, K.; Kegler, C.; Kim, H. U.; Kötter, P.; Krug, D.; Masschelein, J.; Melnik, A. V.; Mantovani, S. M.; Monroe, E. A.; Moore, M.; Moss, N.; Nützmann, H. W.; Pan, G.; Pati, A.; Petras, D.; Reen, F. J.; Rosconi, F.; Rui, Z.; Tian, Z.; Tobias, N. J.; Tsunematsu, Y.; Wiemann, P.; Wyckoff, E.; Yan, X.; Yim, G.; Yu, F.; Xie, Y.; Aigle, B.; Apel, A. K.; Balibar, C. J.; Balskus, E. P.; BaronaGómez, F.; Bechthold, A.; Bode, H. B.; Borriss, R.; Brady, S. F.; Brakhage, A. A.; Caffrey, P.; Cheng, Y. Q.; Clardy, J.; Cox, R. J.; De Mot, R.; Donadio, S.; Donia, M. S.; van der Donk, W. A.; Dorrestein, P. C.; Doyle, S.; Driessen, A. J.; Ehling-Schulz, M.; Entian, K. D.; Fischbach, M. A.; Gerwick, L.; Gerwick, W. H.; Gross, H.; Gust, B.; Hertweck, C.; Höfte, M.; Jensen, S. E.; Ju, J.; Katz, L.; Kaysser, L.; Klassen, J. L.; Keller, N. P.; Kormanec, J.; Kuipers, O. P.; Kuzuyama, T.; Kyrpides, N. C.; Kwon, H. J.; Lautru, S.; Lavigne, R.; Lee, C. Y.; Linquan, B.; Liu, X.; Liu, W.; Luzhetskyy, A.; Mahmud, T.; Mast, Y.; Méndez, C.; Metsä-Ketelä, M.; Micklefield, J.; Mitchell, D. A.; Moore, B. S.; Moreira, L. M.; Müller, R.; Neilan, B. A.; Nett, M.; Nielsen, J.; O’Gara, F.; Oikawa, H.; Osbourn, A.; Osburne, M. S.; Ostash, B.; Payne, S. M.; Pernodet, J. L.; Petricek, M.; Piel, J.; Ploux, O.; Raaijmakers, J. M.; Salas, J. A.; Schmitt, E. K.; Scott, B.; Seipke, R. F.; Shen, B.; Sherman, D. H.; Sivonen, K.; Smanski, M. J.; Sosio, M.; Stegmann, E.; Süssmuth, R. D.; Tahlan, K.; Thomas, C. M.; Tang, Y.; Truman, A. W.; Viaud, M.; Walton, J. D.; Walsh, C. T.; Weber, T.; van Wezel, G. P.; Wilkinson, B.; Willey, J. M.; Wohlleben, W.; Wright, G. D.; Ziemert, N.; Zhang, C.; Zotchev, S. B.; Breitling, R.; Takano, E.; Glöckner, F. O. Nat. Chem. Biol. 2015, 11, 625-631.

(38) Mazza, P.; Monciardini, P.; Cavaletti, L.; Sosio, M.; Donadio, S. Microb. Ecol. 2003, 45, 362-72.

(39) Weber, T.; Blin, K.; Duddela, S.; Krug, D.; Kim, H. U.; Bruccoleri, R.; Lee, S. Y.; Fischbach, M. A.; Müller, R.; Wohlleben, W.; Breitling, R.; Takano, E.; Medema, M. H. Nucleic Acids Res. 2015, 43, W237-43. 